\title{
フレッシャーズセミナー資料集の掲載について
}

第56回総会学術大会・実行委員会企画の中で新しい試み一つとして，「フレッシャーズセミナー・ビギナーのためのQ＆ A」を五つの会場で開催し，多くの会員の方々に参加していただきました．セミナーを有効に進める目的で準備した配布資料 不足で多くの参加者に大変ご迷惑をおかけしたことを陳謝いたします．資料の入手希望が多いため学会誌に揭載することと なりました.

診療現場の技術者の入門/教育および放射線技術学を学ぶ学生の臨床教育等を目的として，各モダリティ，専門分野につい て装置の運用・使用方法, 日常検査中に感じる初歩的な疑問や問題点, 特定の研究テーマを進めるうえでの具体的な実験方 法・測定方法に関するアドバイス，撮影技術のポイントなど，日常業務の中で気軽に聞けない質問点や問題点についてQ＆ A方式で各分野の専門家がていねいに会場で答える方式を企画しました。事前に学会誌で質問募集を行い, 各セミナー担当 の皆様にお願いしてテキストを兼ねた会場配布の資料を準備した経緯があります，学会誌掲載にあたり，一部を加筆・修正 と体裁を統一した資料集としました. 準備が整ったものから順次掲載いたしますので, 会貝の皆様の入門書の一助としてご 利用いただけたら幸甚です。

日本放射線技術学会第56回総会学術大会 大会長 平林 久枝

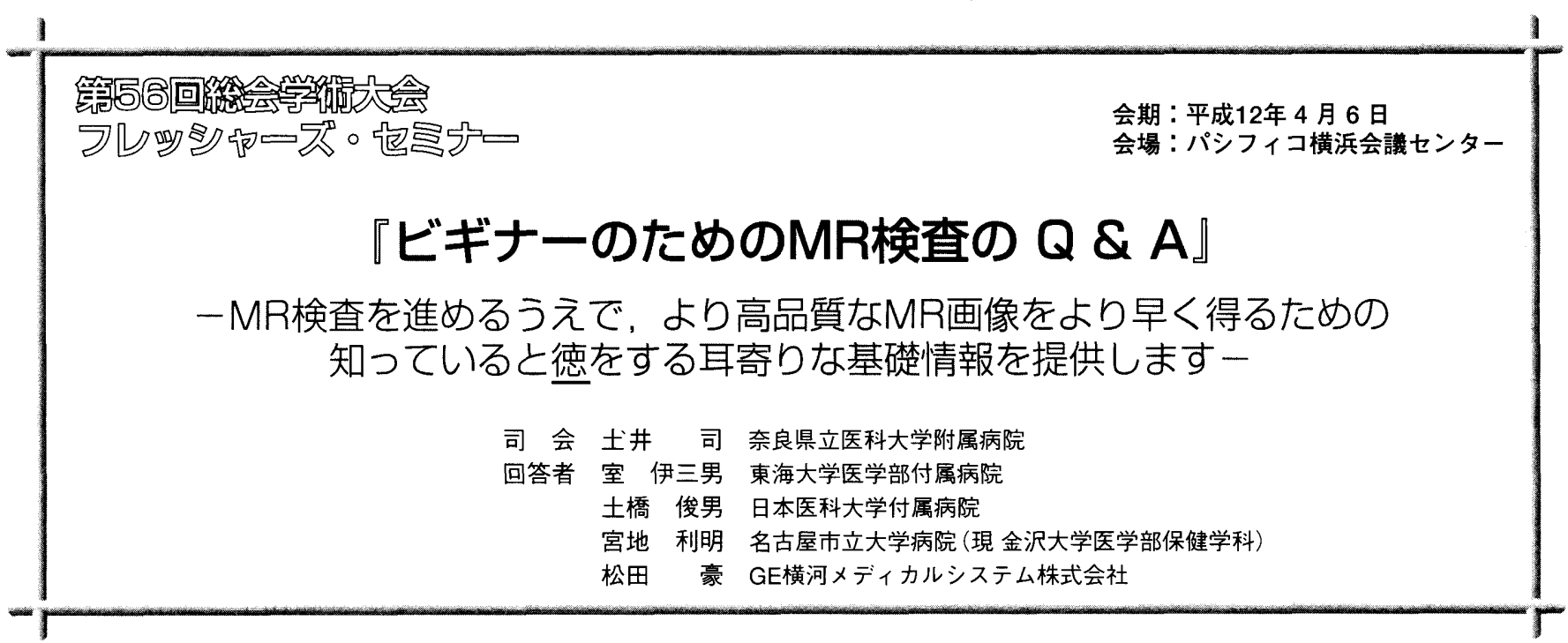

よいMR画像を得るために必要な基礎的な事項から 応用技術，ピットフォール，アーチファクト対策，安 全基準について，最小限の情報を提供できたと思って いる．会場からの質問が少なかったのが意外であった が，聴衆の皆様からの熱気は感じとることができた。

抄録を補足する形で，実行委員会に寄せられた質問 に答える形でセミナーを進行したので，その内容につ いて詳細に語ることはできないが，セミナーの最後に 回答者の皆さんと私とのやり取りに今回のセミナーの 主旨が集約されていると思うので，それを紹介するこ とでこのセミナーのまとめとしたい.

1) 去井：MRに新しい方が配属されてきた時にまず何 を指導(心構え)しますか?

室：患者さんに対する接し方(検査内容の説明，検 査や装置，騒音に対する不安を和らげる心遣い，検 査準備から終了までの取り扱い方など) と，患者さ んに危険が及ぼすことのないよう細心の注意を払う ことをまず指導する。そして，患者さんが検査室内 に禁忌な物質を持ち込まないようにし，装置を安全
に操作することが最も重要なことである。

2) 土井：よい実験データを得る場合のノウハウとは? 宮地：こつやノウハウなどはこれと言ってない.た だ，自分が解明したいことを順序立てて，地道にこ つこつと時間をかけてデー夕を取ることが大切であ る，好きな人は，毎日11時頃まで実験をしている人 もいるとのことである。

土井：そこまでしなくても，毎日少しずつ積み重ね ることでかなりの成果が得られるのでは？

$3)$ 土井：編集委員からみて，MRなどの論文を完成さ せる秘訣は?

土橋：新鮮な命題を見つける目と，いろんなアイデ アがひらめく柔軟な頭を開発することである。そし て，発表された論文や参考文献をよく読み，自分の 主張(言いたいこと)を論理立てて，明解で分かりや すい文章を作ることである。

4) 戈：病院勤めからメーカ側に移られて，オペレー 夕に要望したいことは?

松田：まず，装置を自分の手でいろいろ操作してみ ることが大切である.そうすることで，いろんなメ 
カニズムが理解できるようになり，装置本来の性能 も把握できる．また，検査に対するノウハウやアイ デア，学術研究のテーマを発見することにもつなが る.
以上のコメントと次に続く資料が，今後の皆様の業 務に役立ち, 学術研究に成果を上げられ, 活躍なさる ための参考になれば幸甚です。

\section{Ans (1)}

\section{NMRの偪号はどのようにして行られるのか}

\section{1-1 熱平衡状態}

水素のような原子の周りには電子が回っているため に，右ねじの法則により磁界が発生し，おのおのの原 子は棒磁石と同様な性質を持つと考えられる(Fig. 1).

生体には多くの原子があり，各原子がまちまちな方 向を向いているために，外界からは磁気的な性質が観 察できない。この原子核が任意の磁場にさらされると 原子の方向は揃い，巨視的に磁気的な性質が観察でき るようになる。この巨視的な磁気の大きさは個々の原 子核によって生み出される磁気の強さと，向きが揃う 原子の数で決まり，これらは磁場強度につれ増えるた め, 静磁場強度が高くなるとNMR信号は強くなる. また磁場強度が同じであれば原子核の数に比例するこ とになる。この状態はそのままでいられる状態なので エネルギー的にも安定な熱平衡状態である.

さて，原子の周りの空間を三次元的に考え静磁場方 向を $\mathrm{z}$ とすると，NMR信号は単位時間当たりに変動 の大きな $\mathrm{x}$ - $\mathrm{y}$ 平面からしか受け取れない。またRFも $\mathrm{x}$

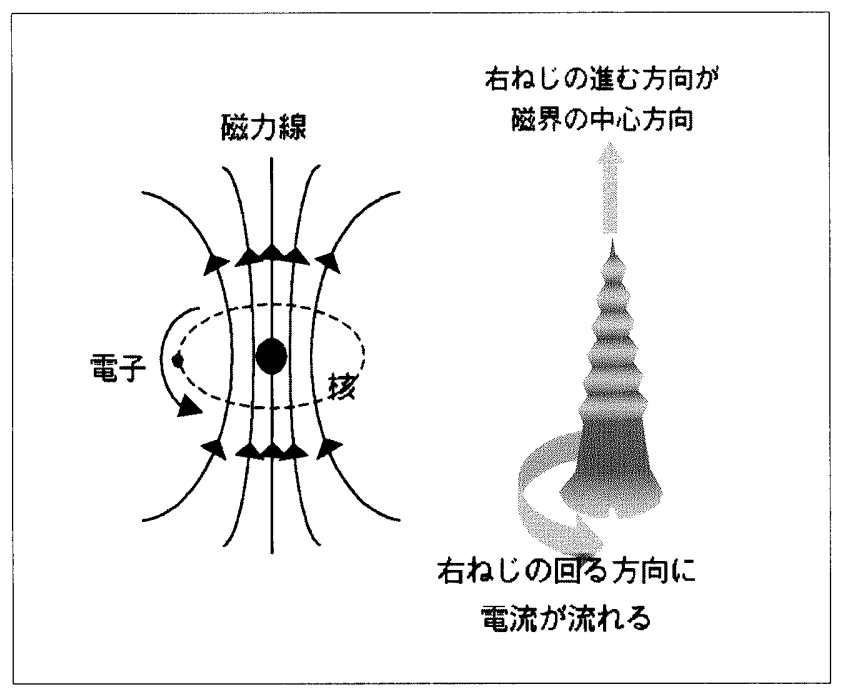

Fig. 1 水素原子と右ねじの法則.
- $\mathrm{y}$ 平面からしか照射できない. したがってNMR信号 強度を考えるときは, $\mathrm{x}-\mathrm{y}$ 平面での信号強度の大きさ を考えればよいことになる。

静磁場がかかっていない状態では, どの方向にも合 成べクトルは現れない。静磁場内の安定な状態では $\mathrm{z}$ 方向には合成磁化ベクトルが発生しているが，安定状 態なので変化が起こらず, $\mathrm{x}$ 一 $\mathrm{y}$ 平面を考えると合成磁 化べクトルは現れないため信号は検出されない(Fig. 2a). なお， $z$ 方向の磁化成分を縦磁化， $x$-y方向の磁 化成分を横磁化と呼んでいる。

\section{1-2 RFによる励起}

任意の磁場にさらされた原子核(Fig. 2a)は，磁場強 度に比例した一定の回転数(周波数)で回っている.こ の回転数と一致するRFを送信すると，原子核はRFの エネルギーを吸収し，RFの回転に沿って回って傾く (励起) (Fig. 2). $\mathrm{z}$ 方向の縦磁化べクトルの倒れる角度 (flip angle) は，一般的にRFの強によって決まる.

\section{1-3 回復過程}

RFの照射が止まると原子核は1-2で受け取ったエ ネルギーをNMR信号として放出して, 元の $\mathrm{z}$ 方向の 安定な状態に戻ろうとする。これがよく書かれている 歳差運動である，歳差運動を起こすと $\mathrm{x}-\mathrm{y}$ 平面に変動 する横磁化べクトルが発生するために, NMR信号が 検出できる. $\mathrm{x}$ - $\mathrm{y}$ 平面上の信号強度は $\mathrm{z}$ 方向のベクト ルが倒れたものであるため, 初めの縦磁化の大きさ と, ベクトルの倒れた角度 (flip angle)によって決まる (Fig. 2b,c). 安定状態に戻るときは，その時の磁場強 度に応じた回転数で回りながらエネルギーを放出し, 元の安定状態の縦磁化の大きさに戻っていく．このよ うに受け取ったエネルギーを放出して安定な状態に戻 るので，エネルギーは周りの原子核に渡すことにな る．周りにエネルギーを渡しやすいと，早く元の安定 状態に戻れることになる。このエネルギーの渡しやす さの指標が縦緩和時間， $\mathrm{T}_{1}$ であり，見方を変えれば 